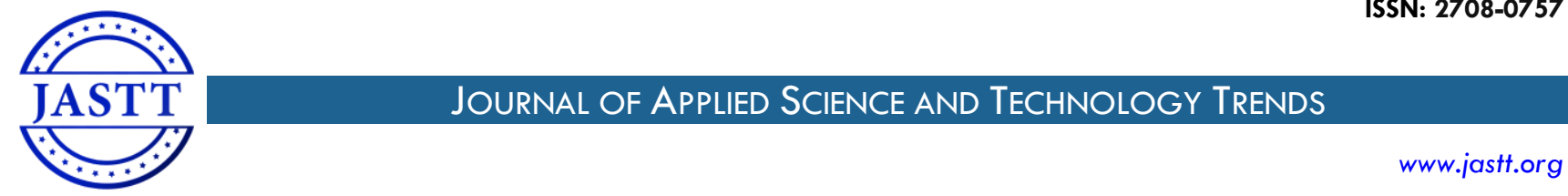

\title{
Effect of Annealing Temperature on Efficiency of Perovskite Solar Cell
}

\author{
Issa M. Aziz ${ }^{1 *}$, Kamil M. Yousif ${ }^{2}$, Naseem S.Abdel ${ }^{1}$ \\ ${ }^{1}$ Department of Physics, Faculty of Science, University of Zakho, Kurdistan Region, Iraq - (issa.aziz57@gmail.com, \\ naseem.salim@uoz.edu.krd) \\ ${ }^{2}$ Department of Environment, Faculty of Science, University of Zakho, Kurdistan Region, Iraq - (kamil.yousif@uoz.edu.krd) \\ * Correspondence: issa.aziz57@gmail.com
}

\begin{abstract}
In this work, a simple method for producing Perovskite solar cells [PSCs] by recycling automobile batteries is used. Trying to get rid of some structures or materials which are harm to the environment (i.e. recycled car batteries) by using lead [Pb] sheets from those battery. Also, by reusing car batteries we will avoid the disposal of toxic battery elements and provide an alternative technique, readily-available Pb source for fabricating PSCs. Perovskite solar cells [PSCs] were prepared by two-step spin coating solution method grown on the FTO glass substrate. The organo-halide PSCs consists of four layers over FTO glass substrate. Lead iodide (PbI $)_{2}$ and methyl-ammonium iodide $\left(\mathrm{CH}_{3} \mathrm{NH}_{3} \mathrm{I}\right)$ used to form the structure of the precursor $\left(\mathrm{CH}_{3} \mathrm{NH}_{3} \mathrm{PbI}_{3}\right)$ by the above-mentioned coating method. The photovoltaic performance of PSCs was investigated, together with the stability of PSCs, and the effect of annealing temperature of PRK layer on performance of PSCs. Characterization of PSCs achieved by using X-ray diffraction, SEM, and Spectrophotometer techniques. The effect of annealing on the optical properties of $\mathrm{MAPbI}_{3}$ films were studied by measuring spectral transmittance. The energy band gap value of the $\mathrm{MAPbI}_{3}$ film was found to be $1.60 \mathrm{eV}$.
\end{abstract}

Keywords: perovskite solar cells, device fabrication, photocells, FTO substrate, X-ray diffraction

Received: July 4, 2020 / Accepted: July 28, 2020 / Online: August 5, 2020

\section{INTRODUCTION}

The third-generation solar cells (PSCs) halide perovskite organic-inorganic solar cells have attracted a great deal of attention of solar cell research community due to an incredible device efficiency improvement from 3.8\% to $22.1 \%$ since 2009 $[1,2]$. PSCs not only solve energy crisis, also reduce the emission of $\mathrm{CO}_{2}$ causes the global warming and eradicating of toxic lead in old car batteries for serving solar energy. The perovskite materials have been demonstrated with largely tunable band gap (e.g., $\mathrm{CH}_{3} \mathrm{NH}_{3} \mathrm{PbX}_{3}$ has a band gap from 1.5 $\mathrm{eV}$ to $2.3 \mathrm{eV}$ ) [3], with a high optical absorption coefficient (more than $10^{4} \mathrm{~cm}^{-1}$ ) [4,5], similar to CdTe [6], copper zinc tin sulfide (CZTS) [7], and other thin film solar cells. It's a lowcost and convenient fabrication techniques as compared to silicon-based devices that require complicated and costly highvacuum deposition methods. Reports of successful cell fabrication on flexible substrates even indicated a greater possibility to the large-scale roll-to-roll manufacturing of PSCs that can be used in the industries [8-10].The initial meaning of "perovskite" was about the crystal structure of calcium titanate, which was discovered in 1839 by the German mineralogist Gustav Rose and was named by the Russian mineralogist Lev Perovski. Since then, the term "perovskite" was referred to all compounds with the same crystal structure as calcium titanate. The perovskite light absorption layer has a general formula of $\mathrm{ABX}_{3}$, where $\mathrm{A}$ is an organic cation (e.g., methyl-ammonium $\mathrm{CH}_{3} \mathrm{NH}_{3}{ }^{+}$), $\mathrm{B}$ is a metal cation (e.g., $\mathrm{Pb}^{2+}$ ) and $\mathrm{X}$ stands for the halide anion (e.g., $\left.\mathrm{I}^{-}\right)$. The perovskite materials have a general crystal structure described as $A B X_{3}$, where " $\mathrm{A}$ " and " $\mathrm{B}$ " are cations with varied sizes and " $\mathrm{X}$ " is an anion. A typical unit cell structure of a basic perovskite compound is shown in Figure 1. Organometallic halide perovskites include an organic cation (e.g., methyl-ammonium $\mathrm{CH}_{3} \mathrm{NH}_{3}{ }^{+}$, ethyl-ammonium $\mathrm{CH}_{3} \mathrm{CH}_{2} \mathrm{NH}_{3}{ }^{+}$, formamidinium $\mathrm{NH}_{2} \mathrm{CH}=\mathrm{NH}_{2}{ }^{+}$), a metal cation of carbon family (i.e., $\mathrm{Ge}^{2+}, \mathrm{Sn}^{2+}, \mathrm{Pb}^{2+}$ ) and a halogen anion (i.e., $\left.\mathrm{F}^{-}, \mathrm{Cl}^{-}, \mathrm{Br}^{-}, \mathrm{I}^{-}\right)$. Among them, methyl-ammonium-leadiodide $\left(\mathrm{MAPbI}_{3}\right)$ is the most widely used perovskite light 
absorber. Some recent research efforts also replaced lead with other metal ions due to the concern of toxicity of lead during device fabrication, especially for the future large-scale manufacturing [11,12].In addition, several organic cations $\left(\mathrm{CH}_{3} \mathrm{NH}_{3}{ }^{+}\right.$and $\left.\mathrm{NH}_{2} \mathrm{CH}=\mathrm{NH}_{2}{ }^{+}\right)$, inorganic cations $\left(\mathrm{Cs}^{2+}\right.$ and $\left.\mathrm{Sn}^{2+}\right)$ and halide anions $\left(\mathrm{Br}^{-}, \mathrm{Cl}^{-}\right.$and $\left.\mathrm{I}^{-}\right)$have been used to improve the efficiency and stability.
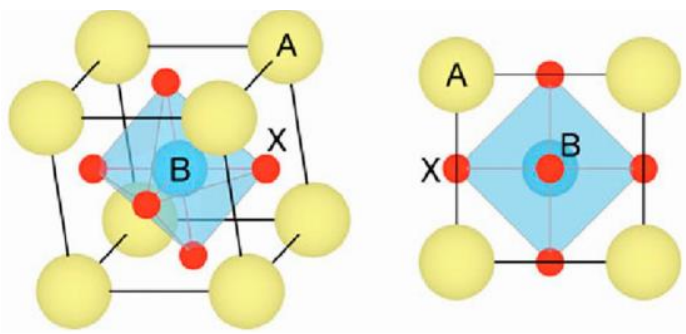

Fig.1. Crystal structure of normal perovskite solar cells of the general formula $\mathrm{ABX}_{3}[13]$.

The PRK has different structures which are temperaturedependent. When the temperature is below $100 \mathrm{~K}$, the unit cell structure will have an orthorhombic phase. When the temperature rose to $160 \mathrm{~K}$, the tetragonal phase $(\beta)$ became visible and replaced the peculiar orthogonal phase $(\gamma)$ [14]. With a further increase in temperature to about $330 \mathrm{~K}$, tetragonal to stable cubic $(\alpha)$ transformation will occur [15]. Figure 2. Shows three different phases.

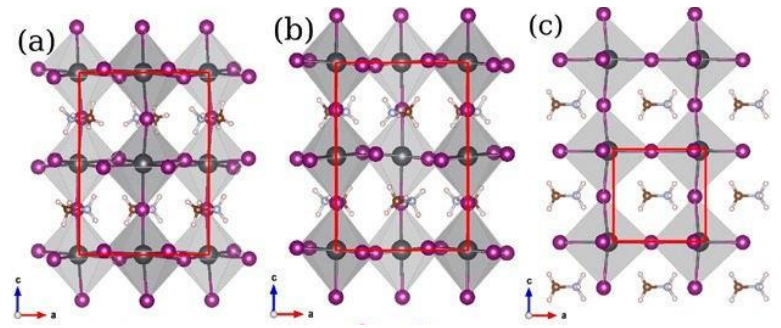

Fig. 2. Comparison between (a) orthorhombic, (b) tetragonal and (c) cubic perovskite crystal structures [16].

\section{Methodology}

\section{A. Sample Preparation}

First disconnect the battery from the car $(12 \mathrm{~V}, 799.7 \mathrm{gm}$ lead) with metallic harvester [17] with a metal cutter. The acidic electrolyte was carefully removed and collected, and the electrode, as well as the inner wall of the car battery, was washed several times with clean water. The electrolyte contains concentrated sulfuric acid $\left(\mathrm{H}_{2} \mathrm{SO}_{4}\right)$. The resulting car battery was dried in ambient conditions for 3 days. The car's dry battery was removed from the top cover and then inspected from the sides to remove the electrode panels. After displacement, the material recovered from the lead is separated the lead (anode) and the lead dioxide (cathode) are separated from the current collectors and diluted successively with $\mathrm{HCl}$ (hydrochloric acid) and wash with clean water. The collected material was ground in powder for further synthesis. Lead dioxide $\left(\mathrm{PbO}_{2}\right)$ must be converted to lead oxide $(\mathrm{PbO})$ using a ceramic crucible to roast lead dioxide $\left(\mathrm{PbO}_{2}\right)$ in a muffle furnace at $600^{\circ} \mathrm{C}$ for 5 hours. After heating Lead Dioxide at $600^{\circ} \mathrm{C}$ for 5 hours it has to be cooled at room temperature. During this process, the color of $\mathrm{PbO}_{2}$ powder was changed from dark brown to yellow color ( $\mathrm{PbO}$ powder). Preparation of Lead Iodide from Lead Acetate Dissolve $3 \mathrm{~g}$ of $\mathrm{PbO}$ (lead oxide) in $5 \mathrm{ml}$ of acetic acid. Preparation of lead iodide from lead nitrate by constant stirring in a magnetic stirrer $3 \mathrm{~g} \mathrm{~Pb}$ in $5 \mathrm{ml}$ of nitric acid and then dissolve $10 \mathrm{ml}$ of potassium iodide, potassium iodide acts as a catalyst to increase the rate. Stirring the solutions for 30 minutes at $500 \mathrm{rpm}$ using magnetic stirrer. Clean the solution by leaving the solution in aerobic position for 1 day, then using a centrifuge, the solution must be filled in centrifuge tubes, then deionized water is added to the solution, then centrifuged at $5000 \mathrm{rpm}$ for 5 minutes to carry out the procedure. Repeat 3 times to completely remove the acid concentration, the precipitate will precipitate due to a change in density, and then the acid concentration must be removed. After centrifuging the solution, the solution has to be dried in aerobic condition during the entire procedure the solution has to be placed in a fume hood or fume cupboard. A fume hood or fume cupboard is a type of local ventilation device that is designed to limit exposure to hazardous or toxic fumes, vapors or dusts. Then, for preparation of methylammonium iodide $\left(\mathrm{CH}_{3} \mathrm{NH}_{3} \mathrm{I}\right)$, First, $\mathrm{HI}$ (Sigma-Aldrich) was mixed with Methylamine $\left(\mathrm{CH}_{3} \mathrm{NH}_{2}\right)$ in methanol and stirred in ice bath until white crystals were formed. Then, methanol was removed and consequently the solution was filtrated to produce white crystals of $\mathrm{CH}_{3} \mathrm{NH}_{3} \mathrm{I}$.

\section{B. Cell Fabrication}

The organo-halide PRK solar cell consists of five layers, the layers is the galss/FTO layer acting as the substrate. The glass/FTO substrates were left and cleaned in (isopropyl alcohol) solution for 30 minutes durations to get rid of any residues and contaminants. The ohmmeter was used to determine the conductive side of the glass/FTO substrates. Afterwards, a $150 \mathrm{~nm}$ thick $\mathrm{TiO}_{2}$ was spin-coated on the glass/FTO substrate which act as the electron transport layer (ETL). In this process. The spin coating speed was set to 3000 r.p.m.. Then, a $300 \mathrm{~nm}$ thick $\mathrm{MAPbI}_{3}$ film was deposited on the $\mathrm{TiO}_{2}$ layer using two-step sequential deposition method [18]. Under a $\mathrm{PbI}_{2} / \mathrm{MAI}$ molar ratio of $3: 1$ condition, the film preparation and deposition was carried out at three different temperatures, as deposited (non- annealed), 100 and $120^{\circ} \mathrm{C}$, respectively. After that, a $100 \mathrm{~nm}$ thick hole transport layer (HTL) of copper iodide (CuI), were deposited on top of the $\mathrm{MAPbI}_{3}$ using centrifugation method. Finally, a $80 \mathrm{~nm}$ thick $\mathrm{Ag}$ layer was thermally evaporated on top of the HTL layer to complete the solar cell device. Thermal evaporation was achieved at a chamber pressure of $10^{-5} \mathrm{mbar}$. The structure of the completed solar cell device is shown in Figure 3.

\section{Characterization of Perovskite Solar Cell}

To fabricate a PRK solar cell a $300 \mathrm{~nm}$ thick of $\mathrm{Ag} / \mathrm{CuI} / \mathrm{MAPbI}_{3} / \mathrm{TiO}_{2}$ structure was deposited on the glass/FTO 
substrate as shown in Figure 3. The efficiency of the fabricated device was measured using light source of AM1.5- illumination [light intensity of $100 \mathrm{~mW} \mathrm{~cm}^{-2}$ at room temperature. The morphology and thickness of PSCs were studied using scanning electron microscopy (SEM)( Model: JSM-7600 F, Jeol). X-ray diffraction (XRD) technique (Model Rigaku ATX-XRD) with $\mathrm{Cu}$ Ka radiation wavelength of $1.5405 \AA$ was used for structural study. UV-Visible Spectrophotometer- [Model Perkin-Elmer lambda 25] was used to investigate the optical properties such as transmittance in the visible \& NIR range.

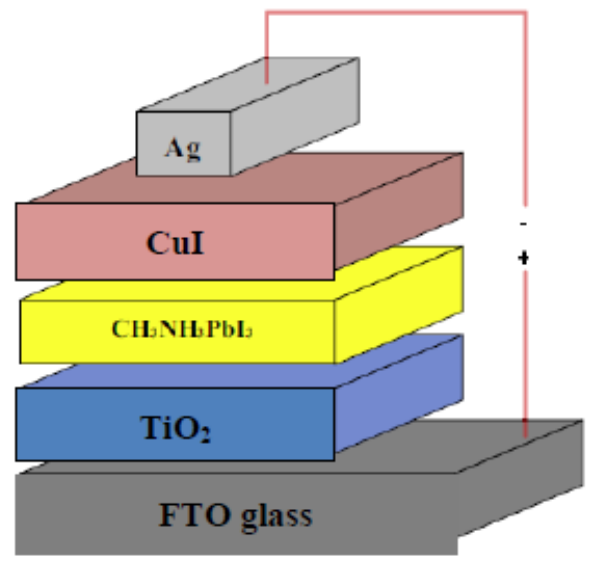

Fig. 3. Schematic of the perovskite device configuration consisting of a glass/ $/ \mathrm{TiO}_{2} /$ Perovskite/CuI/Ag structure.

\section{RESULT AND DISCUSSION}

\section{A. Analyzing the Film's Structure}

Figure 4 shows the effect of three different annealing temperatures on the x-ray diffraction pattern of the $\mathrm{MAPbI}_{3}$ layer incorporated in the solar cell device as previously mentioned in section 1. B. Results show the presence of small $\mathrm{PbI}_{2}$ peaks (110) and (220) at $2 \theta$ angles of $\left(12.6^{\circ}\right)$ and $\left(37.95^{\circ}\right)$, respectively which have been denoted by asterisk. The other peaks denoted by small circle are related to the MAPI observed at $2 \theta$ angles of $\left(13.75^{\circ}\right),\left(20^{\circ}\right),\left(23.4^{\circ}\right),\left(24.3^{\circ}\right),\left(28^{\circ}\right),\left(32^{\circ}\right)$, $\left(35^{\circ}\right),\left(41^{\circ}\right),\left(43^{\circ}\right),\left(50^{\circ}\right),\left(52.3^{\circ}\right),\left(61^{\circ}\right)$, and $\left(68^{\circ}\right)$, respectively. The preferred orientation was observed at $2 \theta$ angle of $\left(13.75^{\circ}\right)$ which is related to MAPI. Based on the experimental observations as the annealing temperature increases the intensity of $\mathrm{PbI}_{2}$ peaks reduces. On the contrary, increase in the annealing temperature resulted in the enhancement of the XRD peak intensity of MAPI. The XRD peaks observed in this study are in agreement with the previous study for cubic MAPI (JCPDS Card No 31-1335) [19].

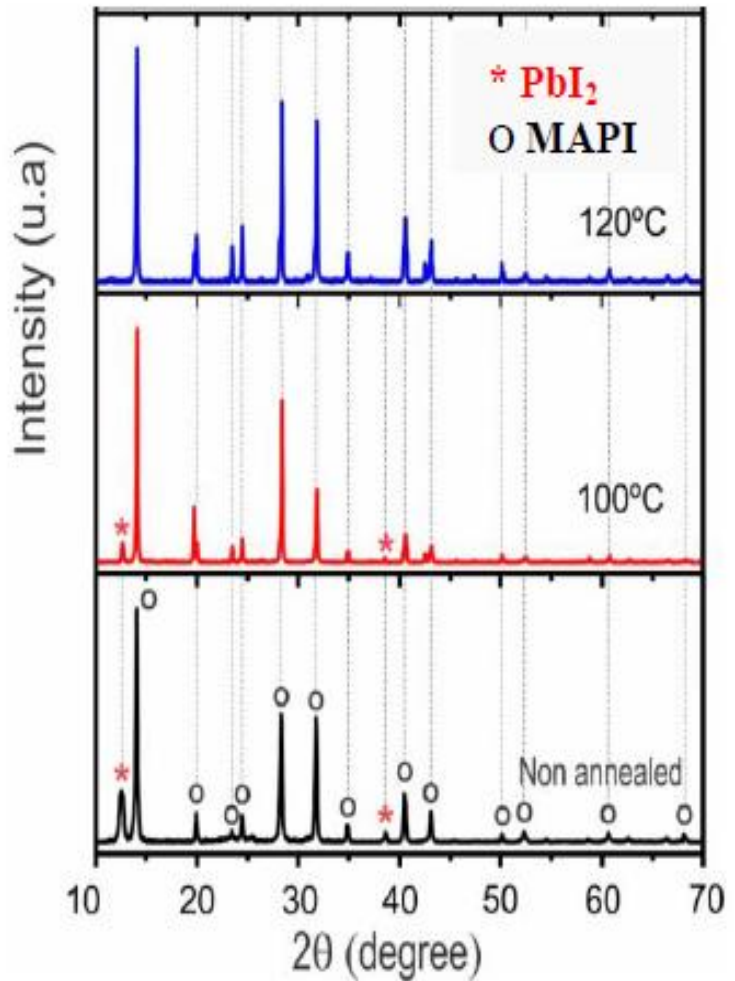

Fig. 4. The X-ray diffraction (XRD) spectrum of a $\mathrm{MAPbI}_{3}$ thin film obtained under three different temperature conditions of as-deposited (room temperature or non-annealed), annealed at $100{ }^{\circ} \mathrm{C}$ and $120^{\circ} \mathrm{C}$ for 15 minutes in air respectively.

\section{B. Morphological Analysis}

Figure 5 shows the SEM images of the $\mathrm{MAPbI}_{3}$ film obtained with a 3:1 $\mathrm{PbI}_{2} / \mathrm{MAI}$ molar ratio at room temperature and annealed after deposition at two different temperatures of 100 and $120^{\circ} \mathrm{C}$, respectively. These results suggest that the annealing significantly changed the morphology of the $\mathrm{MAPbI}_{3}$ film. The as-deposited (non-annealed) $\mathrm{MAPbI}_{3}$ film approximately showed a uniform coverage morphology type with small grains with the average size in the range of $225 \mathrm{~nm}$. After annealing at $100{ }^{\circ} \mathrm{C}$ the increase in the grain size from 150 to $300 \mathrm{~nm}$ was observed, however, some voids have been observed in the SEM image of the annealed sample at $100^{\circ} \mathrm{C}$. With rising temperature up to $120^{\circ} \mathrm{C}$ the $\mathrm{MAPbI}_{3}$ film showed dense pore-free morphology and the average grain size increased to $325 \mathrm{~nm}$. 

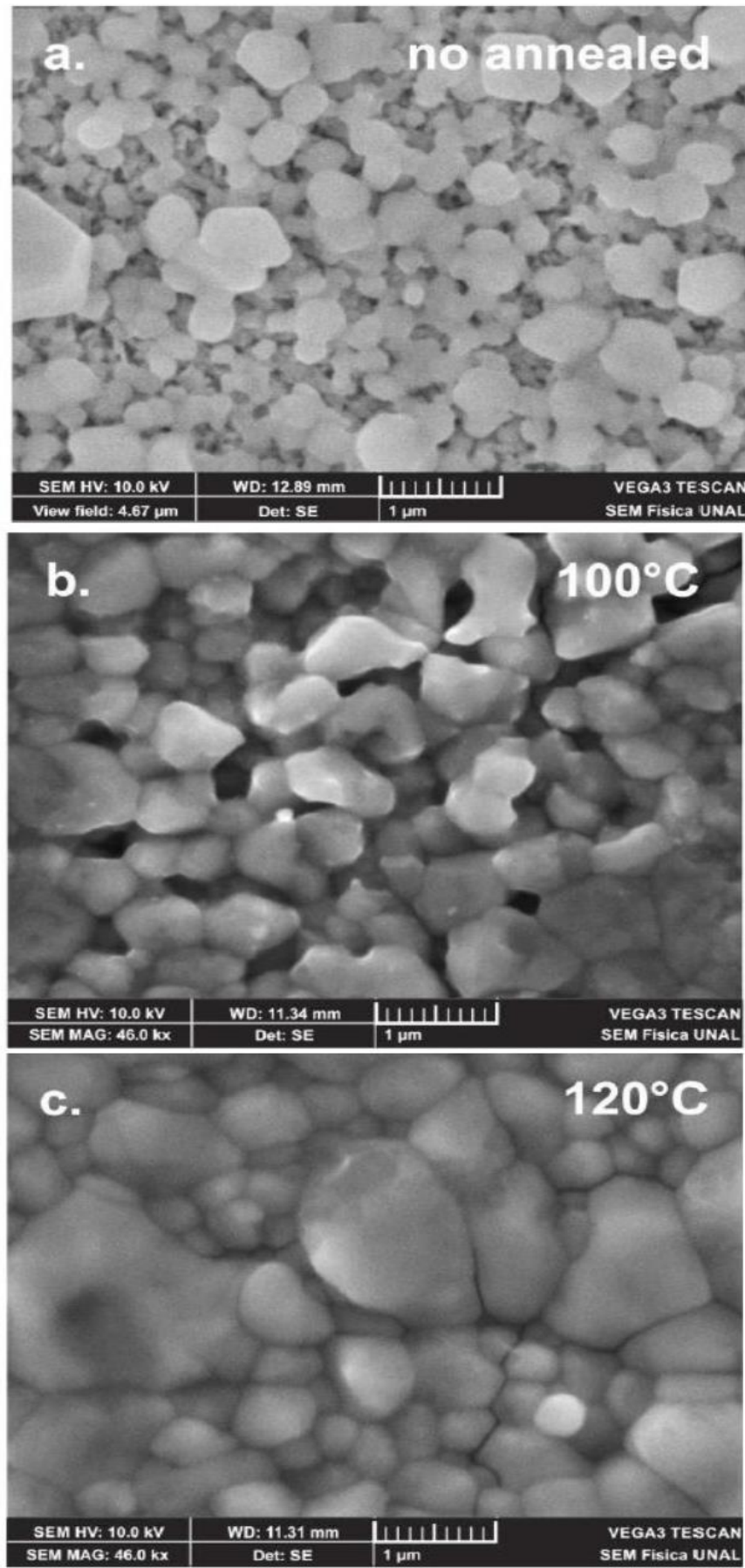

Fig. 5. The SEM images of $\mathrm{MAPbI}_{3}$ film with $\mathrm{PbI}_{2} / \mathrm{MAI}$ molar ratio of $3: 1$ obtained, (a) at room temperature (without annealing), (b) annealed at $100{ }^{\circ} \mathrm{C}$ and (c) annealed at $120^{\circ} \mathrm{C}$, for 15 minutes durations.

\section{Optical Properties}

The effect of two different annealing temperature on the optical properties of $\mathrm{MAPbI}_{3}$ films were studied by measuring spectral transmittance. Figure 6 displays the effect of annealing temperature on the spectral transmittance of the $\mathrm{MAPbI}_{3}$ film obtained at the condition in which $\mathrm{PbI}_{2} / \mathrm{MAI}$ molar ratio was 3:1. Results show the higher transmittance for the non-annealed $\mathrm{MAPbI}_{3}$ film with cut off wavelength of $775 \mathrm{~nm}$. As the annealing temperature increased to $100^{\circ} \mathrm{C}$ and then to $120^{\circ} \mathrm{C}$, subsequently, the transmittance of the $\mathrm{MAPbI}_{3}$ film slightly reduced which indicates the enhancement in optical properties of the film after annealing. Also, after annealing, the cut off wavelengths of the $\mathrm{MAPbI}_{3}$ film were slightly shifted toward the higher wavelength (lower energy photons).

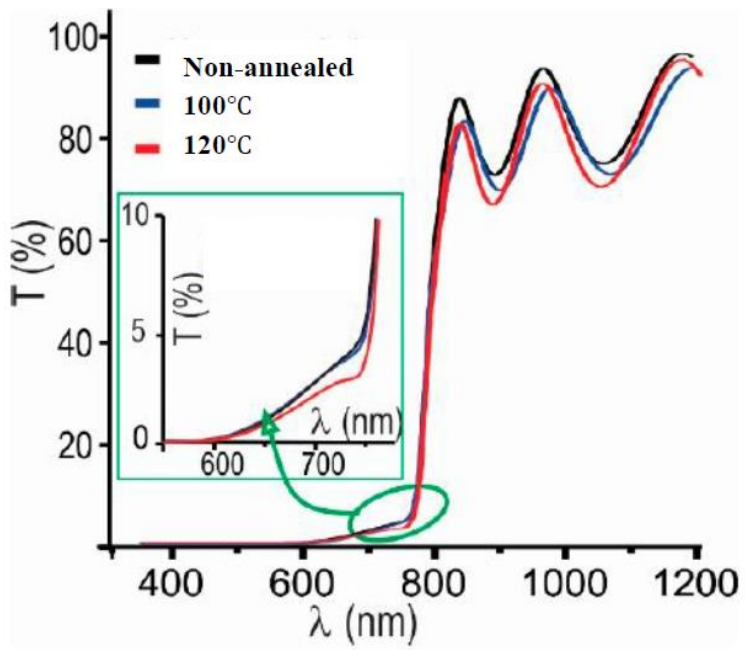

Fig. 6. Effect of annealing temperature on the transmittance of a typical MAPI film prepared under $\mathrm{PbI}_{2} / \mathrm{MAI}$ thickness ratio of 3:1.

Figure 7 shows transmittance and reflectance spectra corresponding to typical $\mathrm{MAPbI}_{3}$ sample free of new phases and in the inset are displayed curves of $(\propto h v)^{2}$ versus $h v$ used to determine the $\mathrm{E}_{\mathrm{g}}$ value. It was found that $\mathrm{MAPbI}_{3}$ film have energy gap of $1.60 \mathrm{eV}$ which is in agreement with the values reported by other authors in the literature [20].

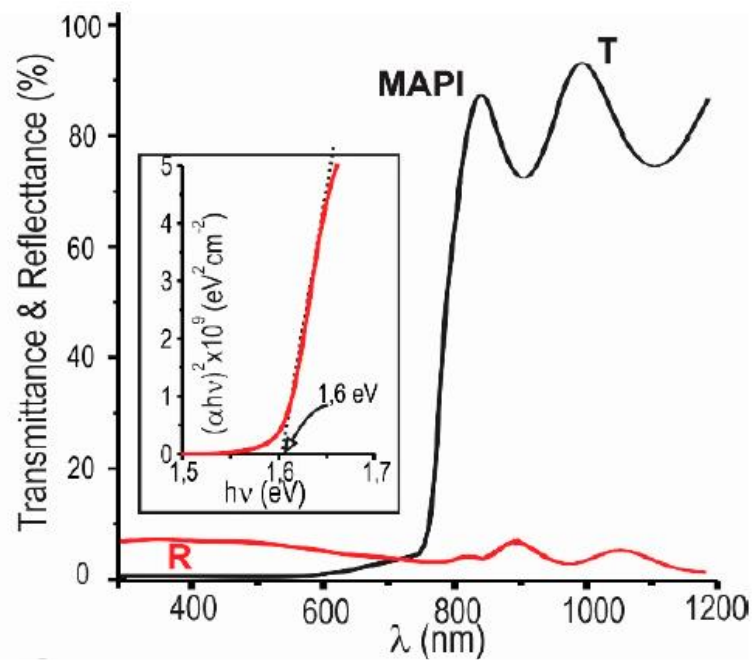

Fig.7. The optical absorption spectra of the non-annealed and annealed $\mathrm{MAPbI}_{3}$ at two different temperatures of 100 and $120^{\circ} \mathrm{C}$, respectively. 


\section{Electrical Characteristics and Assesment of the Fabricated Glass/FTO/ Tion/ Mapbi3/Cui/Ag Solar Cell.}

Solar cells were fabricated with the structure of Glass/FTO/ $\mathrm{TiO}_{2} / \mathrm{MAPbI}_{3} / \mathrm{CuI} / \mathrm{Ag}$, where $\mathrm{MAPbI}_{3}$ is the active layer of the fabricated solar cell. The I-V curves of the fabricated devices were measured under the standard air mass (AM 1.5) with a light source having the irradiance of $100 \mathrm{~mW} / \mathrm{cm}^{2}$ incident on the active area of $1 \mathrm{~cm}^{2}$. To assess the performance of Glass/FTO/TiO $/ 2 \mathrm{MAPbI}_{3} / \mathrm{CuI} / \mathrm{Ag}$ solar cell. the I-V curves were plotted under light condition and the comparison were made for three devices where the active $\mathrm{MAPbI}_{3}$ layer was first kept as non-annealed and this layer was then annealed at two different temperatures of 100 and $120^{\circ} \mathrm{C}$ for 15 minutes in air, respectively and the results is shown in Figure 8.

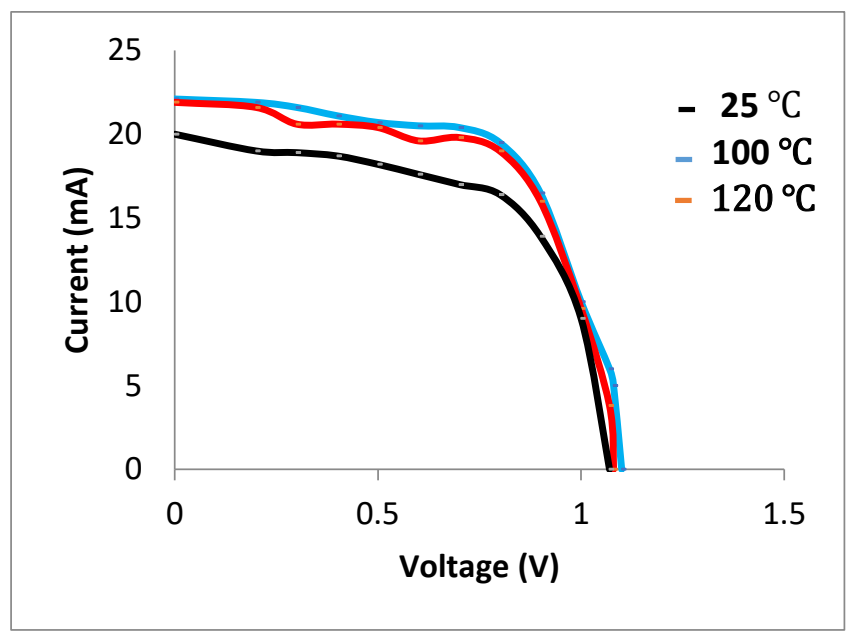

Fig. 8. I-V curves of the fabricated solar cells with the structure of Glass/FTO/ $\mathrm{TiO}_{2} / \mathrm{MAPbI}_{3} / \mathrm{CuI} / \mathrm{Ag}$ obtained at three conditions of non-annealed $\left(25^{\circ} \mathrm{C}\right)$ and annealed at 100 and $120^{\circ} \mathrm{C}$, respectively.

Table I shows the values of the corresponding performance parameters \{ short-circuit current $\left(\mathrm{I}_{\mathrm{sc}}\right)$, open-circuit voltage $\left(\mathrm{V}_{\mathrm{oc}}\right)$, fill factor $(\mathrm{FF})$ and efficiency $(\eta)$ \}, In equation (1) $\mathrm{P}_{\mathrm{m}}$ represents the maximum power that can be extracted from the fabricated solar cells and in equation (2) $\mathrm{P}_{\text {in }}$ and $\mathrm{P}_{\text {out }}$ respectively represents the power of the incident sunlight and solar cell output power [21]. The influence of the annealing temperature on the performance of the fabricated solar cell in this paper is presented (see Table I). The effect of annealing temperature on the performance of the PRK solar cells has been reported by other authors in the literature [22].

$$
\begin{aligned}
\mathrm{FF} & =\frac{\mathrm{p}_{\mathrm{m}}}{\mathrm{V}_{\text {oc }} \mathrm{I}_{\mathrm{sc}}} \\
\eta(\%) & =\frac{\mathrm{P}_{\text {out }}}{\mathrm{P}_{\text {in }}}=\frac{\mathrm{I}_{\mathrm{sc}} \mathrm{V}_{\text {oc }} \mathrm{FF}}{G \mathrm{~A}} \times 100 \%
\end{aligned}
$$

Where $\mathrm{A}$ is active area, and $\mathrm{G}$ is solar irradiance $(1000 \mathrm{Wm}$ ${ }^{2}$ or $\left.100 \mathrm{mWcm}^{-2}\right)$.
TABLE I. EFFECT OF ANNEALING TEMPERATURES ON SOLAR CELL PERFORMANCE

\begin{tabular}{cccccc}
\hline $\begin{array}{c}\text { Sample } \\
\text { ID No. }\end{array}$ & $\begin{array}{c}\text { Annealing } \\
\text { Temperature }\end{array}$ & $\begin{array}{c}\mathrm{I}_{\mathrm{sc}} \\
(\mathrm{mA})\end{array}$ & $\begin{array}{c}\mathrm{V}_{\mathrm{oc}} \\
(\mathrm{V})\end{array}$ & $\mathrm{FF}$ & $\begin{array}{c}\eta \\
(\%)\end{array}$ \\
\hline $\mathrm{S}_{1}$ & $\begin{array}{c}\text { As-deposited } \\
\left(25^{\circ} \mathrm{C}\right)\end{array}$ & 20 & 1.07 & 0.58 & 12.4 \\
\hline $\mathrm{S}_{2}$ & $100^{\circ} \mathrm{C}$ & 22.1 & 1.1 & 0.61 & 14.8 \\
\hline $\mathrm{S}_{3}$ & $120^{\circ} \mathrm{C}$ & 21.9 & 1.08 & 0.60 & 14.2 \\
\hline
\end{tabular}

As part of this work, we were able to produce a cell with efficiency 14.8 after annealing at $100^{\circ} \mathrm{C}$ noting that we used $\mathrm{TiO}_{2}$ and $\mathrm{CuI}$ acting as ETL and HTL layers, respectively.

As can be seen from Figure 8 the main reason for the low efficiency is low FF and low short circuit current $\left(\mathrm{I}_{\mathrm{sc}}\right)$, another reason of observing low FF can be due to the high series resistance of the device. The FF also depends on the quality of the solar cell diode, which is affected by the presence of the trap centers in the degradation zone and layer interfaces. Also, it can be due to the low charge transfer at the $\mathrm{TiO}_{2} / \mathrm{MAPbI}_{3}$ and $\mathrm{CuI} / \mathrm{MAPbI}_{3}$ interfaces. As results of the charge carries recombination at interface states, a high-loss in photocurrent can be observed leading to the lower short-circuit current density as well as lower efficiency. The data reported in Table (1) shows that the annealing temperature of the PRK layer affect the solar cell parameters, thereby affecting the device efficiency. In this research work, the best solar cell parameters were obtained for the layers annealed at $100^{\circ} \mathrm{C}$.

\section{E. Stability of the fabricated cell}

So far, stability of perovskite solar cells is the most challenge factor which is considered as the main barrier to its commercialization, therefore, the $\mathrm{I}-\mathrm{V}$ measurement of the Perovskite solar cells were carried out immediately after device fabrication. The I-V measurements were performed under standard test conditions (solar irradiance of $1000 \mathrm{~W} / \mathrm{m}^{2}$, room temperature of 300K, and AM1.5). The degradation of the PSCs device are due to the deterioration [DTR] of the active layer, the DTR of charge transport layers, and the DTR of electrodes. In this work, thermal decomposition [i.e. degradation] occurred at temperature exceeding $100^{\circ} \mathrm{C}$. The Stability, durability, and DTR of the prepared film \& the fabricated cells are still under research and will be published later in the next paper.

\section{CONCLUSION}

In this paper, we have prepared a thin film with suitable optical properties for solar cell application. The films were prepared by two-step spin coating solution method using precursors of lead iodide synthesized from car battery and methylammonium iodide. The best efficiency of the fabricated solar cells observed in this work was $14.8 \%$. It has been found that $\mathrm{CH}_{3} \mathrm{NH}_{3} \mathrm{PbI}_{3}$ films synthesized using $\mathrm{Pb}$ extracted from car battery, and annealed at $100{ }^{\circ} \mathrm{C}$, showed a better efficiency and performance as compared to other annealing temperatures (nonannealed and $120^{\circ} \mathrm{C}$ Results of X-ray diffraction, indicated that 
the structure of films are affected by different annealing temperatures. The SEM results suggested that the annealing temperature significantly changed the morphology of the $\mathrm{MAPbI}_{3}$ film. Surface morphology study of the film show the layer with small grains before annealing. Then the grain size increased after annealing at 100 and $120^{\circ} \mathrm{C}$. The transmittance of the $\mathrm{MAPbI}_{3}$ film showed reduction after annealing which means better photon harvesting. Also, the cut-off wavelengths $\left(\lambda_{c}\right)$ were shifted slightly toward longer wavelength after annealing at 100 and $120^{\circ} \mathrm{C}$. The energy band gap value of the $\mathrm{MAPbI}_{3}$ film was found to be $1.60 \mathrm{eV}$.

\section{REFERENCES}

[1] Kojima A., Teshima K., Shirai U., Miyasaka T. (2009). Organometallic halide perovskite as sens. of vis light for PV cells. J. Am. Chemical Soc. 131, 6050-51.

[2] National Renewable Energy Laboratory (NREL,2019). Best ResearchCell Eff. Available online: http://www.nrel.gov/pv/assets/images/effciency-chart.png

[3] Jeon, N. J., Noh, J.H ., Yang, W.S ., Kim, Y. C., Ryu, S ., Seo, J ., Seko, S.I. (2015). Perovskite of Composal Eng Mat for high perf solar cells. Nature, 517, 476-480.

[4] Green, M.A., Baillie, A.H., Snaith, H.J. (2014). The emergence of PSCs. Nat. Photonics 2014, 8, 506-514.

[5] Park, N.G. (2015). PSC: Emerging Photovoltaic Technology. Mater Today, $18,65-72$

[6] Rangel-Cordenas, J., Sobral, H. (2017). absorption of optical enhancement in thin films CdTe by micro structuring a silicon substrate. Materials 10, 607.

[7] Shi, Z., Jayatissa, A.H. (2017). One-pot hydrothermal synthesis and fabrication of kesterite $\mathrm{Cu}_{2} \mathrm{ZnSn}(\mathrm{S}, \mathrm{Se})_{4}$ thin films. Prog. Nat. Sci. Mater. Int., 27, 550-555.

[8] Kumar, M.H.; Yantara, N.; Dharani, S.; Graetzel, M.; Mhaisalkar, S.; Boix, P.P.; Mathews, N. (2013). Flexible, low-temperature, solution processed $\mathrm{ZnO}$-based perovskite solid state solar cells. Chem. Commun., 49, 11089-11091.

[9] Liu, D.; Kelly, T.L. (2014). PSCs with a planar heterojunction structure prepared using room-temperature solution processing techniq. Nat. Photonics, 8, 133-138.

[10] Shin S.S., Yang, W.S., Noh, J.H., Suk, J.H., Jeon, N.J., Park, J.H., Kim, J.S., Seong, W.M., Seok, S.I. (2015). High-performance flexible PSCs using $\mathrm{Zn}_{2} \mathrm{SnO}_{4}$, prepared in solution below $100 \mathrm{C}$. The Native Commun., 6,7410 .
[11] Hao, F., Stoumpos, C.C., Cao, D.H., Chang R.P.H., Kanatsidis, M.G. (2014). Lead-free solid-state organic-inorganic halide PSCs. The Native Photonics, 8, 489-494

[12] Zuo, C., Ding L. (2017). Lead-free perovskite materials $\left(\mathrm{NH}_{4}\right)_{3} \mathrm{Sb}_{2} \mathrm{IxBr}_{9}$ x. Angew. Chemical, Int. Edition, 56, 6528-6532.

[13] Bischak, C.G., Hetherington, C.L., Wu, H., Aloni, S., Ogletree, D.F., Limmer, D.T., Ginsberg, N.S. (2017). Origin of reversible photoinduced phase separation in hybrid perovskites. Nano Lett., 17, 1028-1033.

[14] Kawamura Y., Mashiyama H., Hasebe, K. (2002). Structural study of the cubic-tetragonal transition $\mathrm{CH}_{3} \mathrm{NH}_{3} \mathrm{PbI}_{3}$. J. Phys. Soc. Jpn., 71, 16941697.

[15] Whitfield, P.S., Herron, N., Guise, W.E., Page, K., Cheng, Y.Q., Milas I., Crawford, M.K. Structures, phase transitions, and tricritical behavior of hybrid perovskite methylammonium lead iodide. Sci. Rep 2016, 6, 35685.

[16] Korshunova,K.,WinterfeldL., Beekanak W., Runge E. (2016). Thermodyn. stability of mixed methyl. halide $\mathrm{Pb}$ : Sn perovskite. Physical Solid State, 253, 1907-1915.

[17] Yousif, Kamil M \& Abdulgafar, Sayran A. (2019). Low-cost solar selective absorbers by Electrodepositing technique. Publ. in book (Renewable Energy and Sustainable Buildings [ed.ProfA.Sayigh]. Springer International Publ. Switzerland 2019. chpt. 25, Selected Papers from the WREC 2018 .

[18] Burschaka, N. Pellet, S. Moon et al. (2013). "Sequential deposition as a means of efficient perovskite-sensitized solar cells", Vol 1. 499, no. 7458, pages 316-319.

[19] Min-Cherl Jung, Sonia R. Raga, Luis K. Ono \& Yabing Qi(2015). Substantial improvement of perovskite solar cells stability by pinhole-free hole transport layer with doping engineering SCIENTIFIC REPORTS ,5 : 9863,DOI: 10.1038/srep09863

[20] Slimi B., Mollar M., Assaker,I., Kriaa, I.,Chtourou, R., Mari, B., (2016). Perovskite $\mathrm{FA}_{1-\mathrm{x}} \mathrm{MA}_{\mathrm{x}} \mathrm{PbI}_{3}$ for solar cells: film form.\&corr, Energy Procedures, 102, 87-95.

[21] Wang, Y., Liu, X., Zhou, Z., Ru, P., Chen, H., Yang, X., \& Han, L. (2019). Reliable Measurement of Perovskite Solar Cells. Advanced Materials, 31(47), 1803231.

[22] Shi, Z., and Jayatissa, A. (2018). Perovskite-based solar cells: a review of recent developments, materials and processing methods. Materials, 11 (5), 729. 